\title{
Towards a More Agile Public Policy Making
}

\begin{abstract}
This article aims at discussing the values and principles of the so called AGILE management (AGILE methodologies) in the context of public policy making. In particular, an effort is put into answering the question on the possibility of including the AGILE values and principles in the conduct of policy making. Known from the IT sector, AGILE methodologies have been lately drawing more attention of public policy makers in the world. This approach seems to have a big advantage over hitherto applied modes of public operation, as it allows for a quicker adaptation of policies to changes of the environment. At the same time however, it seems to pose much bigger challenges on policy making bodies, as it requires a strong capacity for regulating diversity throughout the policy making processes in real time.
\end{abstract}

Keywords: governance, AGILE methodologies, incrementalism

W stronę bardziej „Zwinnego” prowadzenia polityki publicznej

\section{Streszczenie}

W artykule prowadzona jest dyskusja nad wartościami i zasadami tzw. „Zwinnego” zarządzania (AGILE methodologies) w kontekście polityki publicznej. Następuje próba odpowiedzi na pytanie o możliwość włączenia tych wartości i zasad do procesu realizacji polityki publicznej. Znane z sektora informatycznego metody przyciągają coraz większą uwagę praktyków zaangażowanych w prowadzenie polityki publicznej na świecie. Wydaje się, że podejście to ma dużą przewagę nad dotychczas stosowanymi metodami prowadzenia polityki publicznej, ponieważ pozwala na o wiele szybsze dostosowanie polityki do pojawiających się zmian otoczenia. Jednocześnie jednak, od instytucji prowadzących politykę publiczną w podejściu tym wymaga się na bieżąco silnej zdolności do regulowania zróżnicowania zachodzącego w trakcie realizacji polityki.

Słowa kluczowe: rządzenie, zwinne rządzenie, inkrementalizm 


\section{Introduction}

Public policymaking is the totality of the decisional processes

by which a government decides to deal or not to deal with

a particular problem or concern. It is a never-ending process ${ }^{1}$.

Public policy making seems to be an ever growing challenge in the globalized world. Accelerating complexity on a global scale forces governments to enhance their capabilities of effective action ${ }^{2}$. One of the latest such responses is the expansion of the "agility" of policy making 3 . By "agility" of policy making I understand a relatively constant ability of acquiring quick and adequate responses to influences coming from the policy making environment ${ }^{4}$.

One of the dominant ideas about policy making prevailing in contemporary democratic societies is that governments and stakeholders should effectively communicate, to enhance the chances for acquiring a high quality policy ${ }^{5}$. It is believed that democratic participation helps assure that public decisions are optimal ${ }^{6}$. Although taking place in a variety of forms ${ }^{7}$, participation seems to be perceived as an effective way of conducting public matters in a complex world ${ }^{8}$. At the same time, public policy making practitioners have been often taking for granted that it is actually possible to determine what the public problem or set of complex problems is, and that respective stakeholders are able to communicate with the government. As such it seems that it is obvious that there is a workable way through which a problem could

1 J.M. Shafritz, K.S. Layne, C.P. Borick, Classics of Public Policy, Person Longman, New York 2005.

2 World Bank, Country Data Report for Poland 1996-2012, http://info.worldbank.org/governance/wgi/pdf/c177.pdf; OECD, Poland: Implementing Strategic-State Capability, 2013; A.Z. Kamiński, J. Stefanowicz, Syndrom słabości państwa: Wydolność strategiczna Polski XXI wieku, „Ruch Prawniczy, Ekonomiczny i Społeczny" 2011, p. 11-39.

3 G. Room, Complexity, Institutions and Public Policy: Agile Decision-making in a Turbulent World, Edward Elgar Publishing 2011; C.J. Torrecilla-Salinas et al., Agile in Public Administration: Oxymoron or Reality? An ExperienceRreport, CAiSE.

4 R. Geyer, P. Cairney, Handbook on Complexity and Public Policy, Edward Elgar Publishing 2015; D. Easton, A Systems Analysis of Political Life, 1979.

5 D. Held, Models of Democracy, Polity 2006.

6 This idea rests on the utilitarian assumption, according to which human conduct should lead to as much of happiness as possible, be socially evaluated, and as such treated on the moral basis. James Stuart Mill formulated the “Greatest Happiness Principle”, holding that „actions are right in proportion as they tend to promote happiness, wrong as they tend to produce the reverse of happiness". See: J.S. Mill, Utilitarianism, Longmans, Green and Company 1901, p. 9.

7 S.R. Arnstein, A Ladder of Citizen Participation, "Journal of the American Institute of Planners" 1969, Vol. 35, No. 4, p. 216-224.

8 R.A. Irvin, J. Stansbury, Citizen Participation in Decision Making: is it Worth the Effort?, "Public Administration Review" 2004, Vol. 64, No. 1, p. 55-65. 
be approached and that public decisions under consideration could actually serve to solve the issue at stake. The best example of this rationale is reflected in the policy cycle model, which - although often criticized as non-realistic - provides basic criteria through which a policy making process could be driven. In the policy cycle model it is assumed that public policymaking should follow a series of steps, which most often include agenda setting, policy formulation, policy implementation and policy evaluation ${ }^{9}$. Along with this rationalistic concept of policy making goes the paradigm of public strategic planning ${ }^{10}$. Strategy planning assumes that it is possible to make a clear-cut, logical division between different elements of the long-term planning process $^{11}$. In many models suggested by scholars, it is assumed that the diagnosis of internal and external environment of public organizations should be made separate from formulation and implementation, financing, monitoring and evaluating of its activity $^{12}$. Such an approach still prevails e.g. in Polish administrative theory and practice $^{13}$. Although there are visible efforts that could change $i^{14}$.

Yet, the above waterfall approach proves to be less and less effective, as reality defies imposed structure and logic ${ }^{15}$. Moreover, governments oftentimes lack of capabilities to effectively pursue societal goals in the changing environment, being at the same time forced to cope with a tension between the need for providing stability of the country and the need for change. Since modern governments are responsible for a number of societal functions, such as providing external and internal security on the one hand, and regulating economic and social development of the society on the other, the big challenge remains how the governments should and could operate, to enhance country's viability and resilience ${ }^{16}$. This article aims at discussing some of the recent developments on this matter

The plan of the article is as follows. First, the view on contemporary public policy-making is presented. I provide an overview of the approaches toward complexity

9 W. Jann, K. Wegrich, Theories of the Policy Cycle, "Handbook of Public Policy Analysis" 2006, p. 43-62.

${ }^{10}$ P. Joyce, A. Drumaux, Strategic Management in Public Organizations: European Practices and Perspectives, Routledge 2014.

${ }^{11}$ H. Mintzberg, The Rise and Fall of Strategic Planning, Pearson Education 2000.

12 J.M. Bryson, W.D. Roering, Strategic Planning Options for the Public Sector..., op.cit.

${ }_{13}$ W. Dziemianowicz et al., Planowanie strategiczne. Poradnik dla pracowników administracji publicznej, Ministerstwo Rozwoju Regionalnego, Warszawa 2012.

${ }^{14}$ K. Olejniczak, E. Raimondo, T. Kupiec, Evaluation Units as Knowledge Brokers: Testing and Calibrating an Innovative Framework, "Evaluation" 2016, Vol. 22, No. 2, p. 168-189.

${ }_{15}$ P. Dunleavy et al., New Public Management is Dead-long Live Digital-era Governance, "Journal of Public Administration Research and Theory" 2006, Vol. 16, No. 3, p. 467-494.

16 J. Braithwaite, C. Coglianese, D. Levi-Faur, Can Regulation and Governance Make a Difference?, "Regulation \& Governance" 2007, Vol. 1, No. 1, p. 1-7. 
in public policy domain. Next, AGILE values are briefly described. Finally AGILE principles are discussed in detail.

\section{Public policymaking in the environment of growing complexity}

There were at least two answers to the question of how to handle complexity within policy making scholarship and practice. The first, usually related to Harold Lasswell, asked for rationality of the process, argued for policy making consisting of phases, in which mapping of social and decision processes were logically translated to goals and to means. This approach relies on fostering cross-functional communication of policy actors and domains, and - at the same time - acknowledging authority and control over the process ${ }^{17}$. The scope and nature of public interventions could be relatively radical if they are well designed and implemented ${ }^{18}$. The second approach, associated with Charles Lindblom, suggested a more incremental attitude towards policy making ${ }^{19}$. Lindblom showed how difficult it is to provide conditions for fully rational policy making. For this reason, policy making is supposed to be a step-by-step process, in which steps should be smaller and far more cautious. Thus, the nature and scope of public interventions should be also more conservative. Both have been early discussed on the basis of the relationship between decision makers' scope of information to be gathered and processed and control over environment by Amitai Etzioni ${ }^{20}$. While Lasswell's approach was criticized for its impracticality due to the large amount of information to be processed and the potential for rather revolutionary effects of public interventions, Lindblom's approach was criticized for the limited scope of allowed innovation.

In governance practice, throughout the $20^{\text {th }}$ century, industrialized Western countries have been undergoing a relatively constant change in the ways they conducted

17 This was much later developed into Evidence Based Policy Making (EBPM). See: H.D. Lasswell, The Future of Political Science, Transaction Publishers 1962; H.D. Lasswell, A Pre-view of Policy Sciences, Elsevier Publishing Company 1971.

18 J.L. Pressman, A.B. Wildavsky, Implementation: How Great Expectations in Washington are Dashed in Oakland: or, Why it's Amazing that Federal Programs Work at All, this Being a Saga of the Economic Development Administration as Told by Two Sympathetic Observers who Seek to Build Morals, University of California Press 1984.

19 C.E. Lindblom, The Science of „Muddling through”, “Public Administration Review” 1959, p. 79-88; C.E. Lindblom, E.J. Woodhouse, The Policy-making Process, Prentice-Hall Englewood Cliffs, NJ 1968, Vol. 4.

20 A. Etzioni, Mixed-scanning: A'Third'approach to Decision-making, "Public Administration Review" 1967, Vol. 27, No. 5, p. 385-392. 
public policy making, and gradually enhanced the range of methods and tools while handling growing complexity of the environment. On the theoretical level, governance paradigms have transformed as well - from the ones that have been focused on "centralized power" to the ones that nuanced the relationships between "principal and agent". From the ones that analysed "state institutions" to the ones that researched "public agencies"; and from the ones that concerned "rationalized bureaucracy", to the ones of "new public management" or "network" and "experimentalist governance"21. Oftentimes, governments customized the tools known in industry and applied them to public issues ${ }^{22}$.

However, the globalized world at the beginning of the $21^{\text {st }}$ century is a qualitatively different environment from the one of the 30 preceding years ${ }^{23}$. The world at large has been becoming an area in which people, goods, finance and industries move fast and easily. This challenges countries' capacities for good governance and societies for sustainable co-existence ${ }^{24}$. Due to the development of communication technologies, and transportation networks, as well as migratory fluctuations, less and less could be proclaimed as being controlled directly by public decision-makers, and more and more as that is only influenced or even uncontrolled at all. In addition to multinational corporations, also non-governmental social movements and individuals have they say on how governments could and should work. In effect, the public governance systems and policy making processes are more apt to acknowledge the differentiation within countries and differentiation of external processes ${ }^{25}$.

Governments cope with the turbulences stemming from the environment using the mechanisms of institutional learning and innovation ${ }^{26}$. Learning mechanisms allow for reformulation of policymaking modes of operation and for fostering the chances of a country viability. This process has been evolving from the very beginning

${ }^{21}$ D. Levi-Faur, The Oxford Handbook of Governance, Oxford University Press 2012, file://www. oxfordhandbooks.com/10.1093/oxfordhb/9780199560530.001.0001/oxfordhb-9780199560530; M. Bevir, R.A.W. Rhodes, P. Weller, Traditions of Governance: Interpreting the Changing Role of the Public Sector, "Public Administration" 2003, Vol. 81, No. 1, p. 1-17.

${ }^{22}$ This rationale has also been present for a very long time in the Soviet countries, where the central planning system was used ever since of the communist revolution.

23 J.N. Rosenau, Along the Domestic-foreign Frontier: Exploring Governance in a Turbulent World, Cambridge University Press 1997, Vol. 53; R.O. Keohane, Power and Governance in a Partially Globalized World, "Psychology Press" 2002.

24 S. Sassen, Globalization and its Discontents: Essays on the New Mobility of People and Money, New Press New York 1999, Vol. 9; J.E. Stiglitz, Globalization and its Discontents, New York Norton 2002, Vol. 500; P. Hirst, G. Thompson, S. Bromley, Globalization in Question, John Wiley \& Sons 2015.

${ }_{25}$ M. Andrews, Good Government Means Different Things in Different Countries, "Governance" 2010 , Vol. 23, No. 1, p. 7-35.

262015 Strategic Capacity Report. Strategic Planning, Scholarly Advice, 2015; Governance in a Changing World: Meeting the Challenges of Liberty, Legitimacy, Solidarity, and Subsidiarity, Vatican City 2013, http:// files/462/es14-archer.pdf 
of modern state formation. But learning mechanisms are not enough. Learning must take place at a fast pace, and regard both the substance of the issues within policy domain (s) and the very mode of policy making practice.

One of the latest answers to the governance question of how to adapt best to the dynamic environment is the one provided by scholars working on agile governance ${ }^{27}$. Although the studies on governance agility are at early stage ${ }^{28}$ and when applied to public governance they regard mainly the incentives the new IT tools give to governmental agencies, there is a number of requisites that make the approach valuable for policy making ${ }^{29}$.

\section{Values and principles of AGILE methodologies}

The efforts to make collective goal attainment more "agile" has been most visible in business organizations. It is the result of the stress posed by competitive markets on commercial organizations. These are forced to constantly innovate and better adapt to market conditions, especially in one of the most competitive markets - IT industry. For some practitioners in IT, neither of the "traditional" and other popular approaches to management (e.g. Lean Manufacturing, Kanban, Total Quality Management) proved to be effective enough. That is why they presented an approach that defied many of the management rules hitherto known. In 2001 these practitioners published "AGILE Manifesto", in which they proposed a list of values and principles that were to foster software development process ${ }^{30}$.

The proponents of AGILE methodologies primarily value

INDIVIDUALS AND INTERACTION over processes and tools

WORKING SOFTWARE over comprehensive documentation

CUSTOMER COLLABORATION over contract negotiation

RESPONDING TO CHANGE over following a plan

It seems that these ideas are supposed to enhance the adaptability of the goal attainment process. Since "individuals and interaction" are put in the first place, it appears that software development process should be driven primarily by people and synergetic dynamics between them. Such a group of people is supposed to provide

${ }^{27}$ S. Parker, J. Bartlett, Towards Agile Government, Demos 2008.

${ }_{28}$ A.J.H. d. O. Luna, P. Kruchten, H.P. de Moura, GAME: Governance for Agile Management of Enterprises: A Management Model for Agile Governance, 2013, p. 88-90.

${ }^{29}$ P. Dunleavy et al., New Public Management is Dead-long Live Digital-era Governance..., op.cit.; C. Baker, C. Durante, E. Sanín-Gómez, Agile Government: It's Not an Oxymoron, "Executive Agenda: Ideas and Insights for Business Leaders" 2004, Vol. 7, No. 1, p. 57-65.

${ }^{30}$ Agile Manifesto, 2001, http://agilemanifesto.org/ 
a "working software" to "customer". Feedback loops between members of small, "self-organizing, cross-functional" teams and customers are supposed to be the leading mechanism of product development ${ }^{31}$. "Customer collaboration" is understood as a process itself - in order for the company to submit a final product (working software), it should be able to effectively communicate with customers, who could frequently provide feedback on each of the more and more advanced versions of the product. The values describe the process of software development as an incremental one - small steps are interdependent and the course of action is supposed to be determined not before, but throughout the process. The description and idealization of the product to be delivered is thus minimized. Through focusing on tasks that are easy to identify, the time frame of each project shortens. "Responding to change" underlines the importance of the need for adaptation.

The combined set of four, interlinked values and principles gives a basis for a feasible way of overcoming what was hitherto one of the most aggravating problems for IT projects - the time-lag. The creators of AGILE Manifesto assumed that the key to successful implementation of IT projects was to shorten the lag stretching from the introductory idea to product implementation. At the same time, there are no words in the Manifesto about the need of plans, procedures and authority (e.g. decision bodies), which are implemented in dominant business management frameworks, even process management ${ }^{32}$. As such, these values seem to offer a way of thinking in which teams work constantly on solutions with tools and methods that seem most feasible at the particular moment.

The four values of AGILE Manifesto have been extended into twelve principles, listed in Table 1 and discussed in detail in the following paragraph.

Table 1. Principles of AGILE methodologies ${ }^{33}$

\begin{tabular}{|c|l|}
\cline { 2 - 3 } \multicolumn{1}{c|}{} & \multicolumn{1}{c|}{ Principle } \\
\hline 1. & Our highest priority is to satisfy the customer through early and continuous delivery of valuable software. \\
\hline 2. & $\begin{array}{l}\text { Welcome changing requirements, even late in development. Agile processes harness change for the } \\
\text { customer's competitive advantage. }\end{array}$ \\
\hline 3. & $\begin{array}{l}\text { Deliver working software frequently, from a couple of weeks to a couple of months, with a preference to the } \\
\text { shorter timescale. }\end{array}$ \\
\hline 4. & Business people and developers must work together daily throughout the project. \\
\hline
\end{tabular}

31 What is Agile, https://www.agilealliance.org/agile101/what-is-agile/

32 W.M.P. Van Der Aalst, A.H.M. Ter Hofstede, M. Weske, Business Process Management: A Survey, "International Conference on Business Process Management", Springer 2003, s. 1-12; T.R. Gulledge Jr, R.A. Sommer, Business Process Management: Public Sector Implications, "Business Process Management Journal" 2002, Vol. 8, No. 4, p. 364-376.

33 The bolded text is provided by author of this article. 
Principle

\begin{tabular}{|c|l|}
\hline 5. & $\begin{array}{l}\text { Build projects around motivated individuals. Give them the environment and support they need, and trust } \\
\text { them to get the job done. }\end{array}$ \\
\hline 6. & $\begin{array}{l}\text { The most efficient and effective method of conveying information to and within a development team is a face- } \\
\text { to-face conversation. }\end{array}$ \\
\hline 7. & Working software is the primary measure of progress. \\
\hline 8. & $\begin{array}{l}\text { Agile processes promote sustainable development. The sponsors, developers, and users should be able } \\
\text { to maintain a constant pace indefinitely. }\end{array}$ \\
\hline 9. & Continuous attention to technical excellence and good design enhances agility. \\
\hline 10. & Simplicity - the art of maximizing the amount of work not done--is essential. \\
\hline 11. & The best architectures, requirements, and designs emerge from self-organizing teams. \\
\hline 12. & $\begin{array}{l}\text { At regular intervals, the team reflects on how to become more effective, then tunes and adjusts its } \\
\text { behaviour accordingly. }\end{array}$ \\
\hline
\end{tabular}

\section{Discussion of AGILE values and principles in public policy making}

Are then AGILE methodologies adequate for public policy making? What brings agile methodologies closer to public policy making - the similarities, and what makes them separate? And what "agility" in policy making denote in the first place?

Concluding from the analysis of values presented in the previous paragraph, one might define "agile policy making" as an incremental process, through which fast, short-term results are achieved and evaluated collaboratively by government representatives and citizens. The "agile policy making" values seem to stress that different elements of policy process should be combined.

In effect, one could show important features that makes AGILE principles suitable for public policy making. The adequacy seems to lie especially on the level of goals. It seems that the final goal of companies in IT industry is not a "working software", but "customer satisfaction". And a similar goal could be framed for public policy making. It is not the policy that is the goal of public institutions, but "citizens well-being" or "experience utility" of citizens being directly involved in the process or finding themselves as recipients of outcomes of a policy ${ }^{34}$. In both fields - IT and public policy making - the goals are to be attained throughout a process in which very often there is a need of "changing requirements" of the products (working software or policy), even at the end of the undergoing process. It could not only stem from the "objective" factors, such as the shift of "customer" and "citizens" needs, but from the

34 D. Kahneman, R. Sugden, Experienced Utility as a Standard of Policy Evaluation, "Environmental and Resource Economics" 2005, Vol. 32, No. 1, p. 161-181. 
change of perceptions and expectations of the problems under scrutiny. Moreover, due to fact that certain policy problems emerge and are solved, another set of issues emerge. This makes "sustainable development" an indefinite process, and asks for "continuous attention" 35 .

It also seems that the AGILE principle of "regular reflections" on how a team may become more effective could be equally applied to public policy makers and stakeholders. Although "tuning and adjusting" behavior could pose much more discrepancies and discussions in public domain than in IT industry, learning is a sine qua non condition of innovation ${ }^{36}$.

On the other hand, there are far bigger difficulties in adapting AGILE values and principles to policy making which could be found on the level of policy requirements. First and foremost, governments are accountable for regulating the actions of members of the society as a whole. The governments' role is to make sure that policies are acceptable once identified problems are solved. At the same time, governments need to implement particular policies that will be acceptable in the context of other policies.

Since governments are responsible for effects of public interventions (their outputs and outcomes), the question on what should be the public choice becomes crucial. There is an ongoing struggle over the definition of the problems, which have a chance of becoming an issue within public domain. Public sphere is full of conflicting values, ideas, needs and interests. Thus, the very goal and scope or nature of intervention is never possible to define clearly. It is much easier for commercial organizations to decide on the actual goals and needs of the company - since the mission of the company is to gain profit from its activity.

However, an issue of a choice, is not really present in the AGILE Manifesto. It seems that team members are to decide collectively on the particular actions to be taken in each of the sprints (phases of software development) ${ }^{37}$. It is possible because members of the teams treat themselves as competent in their fields and having similar goals (which is finishing a project). Moreover, AGILE values and principles in IT industry prove to be usable because the choice of the course of action is done by individuals that have chance of receiving immediate response from the customers. In public policy making, there are far more "citizens" and not "customers", whose needs are more complex and sometimes conflicting and it is much more difficult to determine the actual feedback from the citizens. This is also the reason why policy processes have been highly regulated. This also undermines the possibility of

${ }^{35}$ Compare with a garbage can model in policy making. M.D. Cohen, J.G. March, J.P. Olsen, A Garbage Can Model of Organizational Choice, "Administrative Science Quarterly” 1972, Vol. 17, No. 1, p. 1-25.

36 For example, this postulate is rarely implemented in Poland, due to rigidity of legal regulations.

37 This is visible especially in one of the AGILE implementations - SCRUM Framework. 
implementing "face-to-face conversation" mode of operation. The dominant model of public policy making has been until now most often formal. The relations between the state or public institutions and citizens were based on freedoms, obligations and mutual regulations.

It is also an open question what the equivalent of AGILE "working software" in public policy domain might be, as providing one is the primary measure of progress. Theoretically, in public domain all the policies should be working, yet what the criteria are for determining what is actually working or not is a subject of constant debate. It thus undermines another AGILE principle - the "simplicity" principle. Working on policy has been complex. Public regulations should aim at providing simple tools and measures, yet the practice of policy process shows that formulating them in a useful manner has been far more complicated.

Another difficulty stems from the time horizon of the policies. Ideally, policies should last for years (e.g. foreign policy), decades (e.g. health policy), or even generations (e.g. pension policy). Thus monitoring and evaluation criteria of a given policy should be relatively stable. If one takes seriously the principle of incremental design and conduct inherent in AGILE manifesto one should be at least capable of defining the conditions in which the evaluation criteria should be changed within a given time-scale. It would also require that policy makers should accept from the very beginning that there would be a deviation in the public goals and strategic choices. The constant monitoring would most probably also require much bigger resources on the side of the government to be engaged.

$$
* * *
$$

When one considers the applicability of AGILE methodologies to public policy making one should acknowledge that at a certain level of analysis the AGILE values seem complementary to public policy making. Yet, when it comes to AGILE principles, which are more practical and technical in nature, some major problems emerge.

Firstly, it seems that the most significant issue is how an AGILE of "working software" should be understood in public domain. Whether it is a societal "output" of the policy making process, an "outcome" of the policy, or maybe is it the policy making process itself?

Secondly, one should remember the specific characteristics of a policy domain - a space of interlinked, complex, and conflicting values and interests in which the problem of policy choice is immersed in the political struggle, which poses burdens on the process of finding and executing solutions.

Finally, present implementations of this way of thinking in the United States, the United Kingdom and Australia are more focused on the goal attainment in the rational 
sense - in all of these countries a major effort is put to the measurement of goal attainment ${ }^{38}$. The promoters provide the public with a very long list of practical tools and techniques that foster group work of public representatives and citizens - from the idea generation to policy evaluation. Thus, the policy making process, although aimed at a rationalized goal attainment, becomes an art of the engaged participants.

One may conclude that in the future versions of AGILE policy making could provide relatively easy proof of working values and principles that would make the "muddling through" a more simple and rational set of rules of collective actions.

\section{Bibliography}

2015 Strategic Capacity Report. Strategic Planning, Scholarly Advice, 2015.

A pre-view of Policy Sciences, Elsevier Publishing Company, 1971.

An Introduction to Open Policy Making and Design, https://www.gov.uk/guidance/open-policy-

making-toolkit/getting-started-with-open-policy-making\#agile-intro

Agile Government Leadership, http://www.agilegovleaders.org/get-involved/

Agile Manifesto, 2001, http://agilemanifesto.org/

Andrews M., Good Government Means Different Things in Different Countries, "Governance" 2010, Vol. 23, No. 1.

Arnstein S.R., A Ladder of Citizen Participation, "Journal of the American Institute of Planners" 1969, Vol. 35, No. 4.

Baker C., Durante C., Sanín-Gómez E., Agile Government: It's Not an Oxymoron, "Executive Agenda: Ideas and Insights for Business Leaders" 2004, Vol. 7, No. 1.

Bevir M., Rhodes R.A.W., Weller P., Traditions of Governance: Interpreting the Changing Role of the Public Sector, "Public Administration" 2003, Vol. 81, No. 1.

Braithwaite J., Coglianese C., Levi-Faur D., Can Regulation and Governance Make a Difference?, "Regulation \& Governance" 2007, Vol. 1, No. 1.

Bryson J.M., Roering W.D., Strategic Planning Options for the Public Sector, "Handbook of Public Administration" 1996, Vol. 2.

Cohen M.D., March J.G., Olsen J.P., A Garbage Can Model of Organizational Choice, "Administrative Science Quarterly" 1972, Vol. 17, No. 1.

Dunleavy P., Margetts H., Bastow S., Tinkler J., New Public Management is Dead-long Live Digital-era Governance, "Journal of Public Administration Research and Theory" 2006, Vol. 16, No. 3.

${ }^{38}$ An introduction to Open Policy Making and design, https://www.gov.uk/guidance/open-policy-making-toolkit/getting-started-with-open-policy-making\#agile-intro; Agile Government Leadership, http://www.agilegovleaders.org/get-involved/. See also the EU effort toward more agile policy making implemented in the platform "Futurum" - http://ec.europa.eu/futurium/ 
Dziemianowicz W., Szmigiel-Rawska K., Nowicka P., Dąbrowska A., Planowanie strategiczne. Poradnik dla pracowników administracji publicznej, Ministerstwo Rozwoju Regionalnego, Warszawa 2012.

Easton D., A Systems Analysis of Political Life, 1979.

Etzioni A., Mixed-scanning: A 'Third'approach to Decision-making, "Public Administration Review" 1967, Vol. 27, No. 5.

Geyer R., Cairney P., Handbook on Complexity and Public Policy, Edward Elgar Publishing 2015.

Governance in a Changing World: Meeting the Challenges of Liberty, Legitimacy, Solidarity, and Subsidiarity, Vatican City 2013, http://files/462/es14-archer.pdf

Gulledge Jr T.R., Sommer R.A., Business Process Management: Public Sector Implications, "Business Process Management Journal" 2002, Vol. 8, No. 4.

Held D., Models of Democracy, Polity 2006.

Hirst P., Thompson G., Bromley S., Globalization in Question, John Wiley \& Sons, 2015.

Irvin R.A., Stansbury J., Citizen Participation in Decision Making: Is it Worth the Effort?, "Public Administration Review” 2004, Vol. 64, No. 1.

Jann W., Wegrich K., Theories of the Policy Cycle, "Handbook of Public Policy Analysis" 2006.

Joyce P., Drumaux A., Strategic Management in Public Organizations: European Practices and Perspectives, Routledge 2014.

Kahneman D., Sugden R., Experienced Utility as a Standard of Policy Evaluation, "Environmental and Resource Economics" 2005, Vol. 32, No. 1.

Kamiński A.Z., Stefanowicz J., Syndrom słabości państwa: Wydolność strategiczna Polski XXI wieku, „Ruch Prawniczy, Ekonomiczny i Społeczny” 2011.

Keohane R.O., Power and Governance in a Partially Globalized World, "Psychology Press" 2002.

Lasswell H.D., The Future of Political Science, “Transaction Publishers” 1962.

Levi-Faur D., The Oxford Handbook of Governance, Oxford University Press 2012, file://www.oxfordhandbooks.com/10.1093/oxfordhb/9780199560530.001.0001/oxfordhb-9780199560530

Lindblom C.E., The Science of "Muddling through", "Public Administration Review" 1959.

Lindblom C.E., Woodhouse E.J., The Policy-making Process, Prentice-Hall Englewood Cliffs, Vol. 4, NJ 1968.

Luna A.J.H. d. O., Kruchten P., Moura H.P. de, GAME: Governance for Agile Management of Enterprises: A Management Model for Agile Governance, 2013.

Mill J.S., Utilitarianism, Longmans, Green and Company, 1901.

Mintzberg H., The Rise and Fall of Strategic Planning, Pearson Education, 2000.

OECD, Poland: Implementing Strategic-State Capability, 2013.

Olejniczak K., Raimondo E., Kupiec T., Evaluation Units as Knowledge Brokers: Testing and Calibrating an Innovative Framework, "Evaluation" 2016, Vol. 22, No. 2.

Parker S., Bartlett J., Towards Agile Government, Demos, 2008. 
Pressman J.L., Wildavsky A.B., Implementation: How Great Expectations in Washington are Dashed in Oakland: Or, why it's Amazing that Federal Programs Work at all, this Being a Saga of the Economic Development Administration as Told by Two Sympathetic Observers who Seek to Build Morals, University of California Press, 1984.

Room G., Complexity, Institutions and Public Policy: Agile Decision-making in a Turbulent World, Edward Elgar Publishing, 2011.

Rosenau J.N., Along the Domestic-foreign Frontier: Exploring Governance in a Turbulent World, Cambridge University Press, 1997, Vol. 53.

Sassen S., Globalization and Its Discontents: Essays on the New Mobility of People and Money, New Press, New York 1999, Vol. 9.

Shafritz J.M., Layne K.S., Borick C.P., Classics of Public Policy, Person Longman, New York 2005.

Stiglitz J.E., Globalization and its Discontents, Norton, New York 2002, Vol. 500.

Torrecilla-Salinas C.J., Sedeño J., Escalona M.J., Mejías M., Agile in Public Administration: Oxymoron or Reality? An Experience Report, CAiSE.

World Bank, Country Data Report for Poland 1996-2012, http://info.worldbank.org/governance/wgi/pdf/c177.pdf

What is Agile, b.d., https://www.agilealliance.org/agile101/what-is-agile/

Van Der Aalst W.M.P., Ter Hofstede A.H.M., Weske M., Business Process Management: A Survey, CONF, "International Conference on Business Process Management”, Springer, 2003. 
006_SzPP 3_2016.indb 54 